\title{
Effect of Oyster Shell Calcium Powder on the Quality of Restructured Pork Ham
}

\author{
Jung-Seok Choi ${ }^{1,2}$, Hyun-Jin Lee ${ }^{1}$, Sang-Keun Jin², Hyun-Joo Lee ${ }^{3}$, and Yang-II Choi ${ }^{1, *}$ \\ ${ }^{1}$ Department of Animal Science, Chungbuk National University, Cheongju 361-763, Korea \\ ${ }^{2}$ Department of Animal Resources Technology and Swine Science \& Technology Center, \\ Gyeongnam National University of Science and Technology, Jinju 660-758, Korea \\ ${ }^{3}$ Department of Nutrition and Culinary Science, Hankyong National University, Ansung 456-749, Korea
}

\begin{abstract}
This study was conducted to evaluate the effects of oyster shell calcium powder (OSCP) as a substitute for phosphates in curing agent, on the quality of restructured pork ham. Restructured pork ham was processed under six treatment conditions: T1 (no additives), T2 (0.3\% sodium tripolyphosphate), T3 (1.5\% NaCl $+0.5 \%$ whey protein), $\mathrm{T} 4(1.5 \% \mathrm{NaCl}+0.5 \%$ whey protein $+0.15 \%$ OSCP), T5 $(1.5 \% \mathrm{NaCl}+0.5 \%$ whey protein $+0.3 \% \mathrm{OSCP})$, and $\mathrm{T} 6(1.5 \% \mathrm{NaCl}+0.5 \%$ whey protein $+0.5 \%$ OSCP). Addition of OSCP significantly increased the ash content and $\mathrm{pH}$ of restructured pork ham $(p<0.05)$, but did not affect the cooking loss and water holding capacity values of restructured pork ham. Addition of OSCP had no effect on Hunter $a$ and $b$ surface color values of restructured pork ham, but did decrease the Hunter $L$ surface color value $(p<0.05)$. The addition of $0.5 \%$ OSCP showed significantly higher chewiness and springiness values of restructured pork ham, compared with the addition of phosphates $(p<0.05)$. In conclusion, the addition of OSCP combined with low $\mathrm{NaCl}$ and $0.5 \%$ whey protein can be considered a viable substitute for phosphates in the curing agent, when processing restructured pork ham.
\end{abstract}

Key words: OSCP, tripolyphosphate, restructured pork ham, texture, curing agent.

\section{Introduction}

Meat products are one of the most popular foods in the world. In Korea, consumption of meat and meat products has not only increased, but also consumers expect better quality and healthy food products.

Phosphates, like many other curing agents, perform multiple functions when added to meat products. One of the most important functions of phosphates is to increase solubility of meat proteins and their ability to bind and retain water. Water retention capacity improves cooking yield, meat color, tenderness, juiciness and overall texture in terms of quality properties in meat (Song, 1993; Tompkin, 1984; Xiong, 2005). While many forms of phosphates are allowed for use in curing meat, there are no strict regulations that dictate the use of specific phosphates and phosphate blends. The only restriction placed

*Corresponding author: Yang-Il Choi, Department of Animal Science, Chungbuk National University, Cheongju 361-703, Korea. Tel: +82-43-261-2550, Fax: +82-43-272-2240, E-mail: yangilchoi@chungbuk.ac.kr is that the levels of phosphate can not exceed $0.5 \%$ based on the finished product weight when used to reduce moisture loss, protect flavor, or as a curing agent (USDAFSIS, 1982).

Although phosphorus is an essential mineral for maintenance of health, too much intake could inhibit $\mathrm{Ca}$ absorbtion and formation of bone (Virpi et al., 2006). Nowadays also concerns of consumers regarding the use of chemical curing agents like as phosphate, nitrite and preservatives to meat products have been increasing, as well as several studies have tried to substitute for chemical additives to meet the consumer's need in meat products. (Joseph and James, 2007; Manzoor et al., 2014; Park et al., 2012a, 2012b; Park et al., 2008). For these reasons, elimination of phosphates has been attempted in meat product industry currently.

Oyster shells contain calcium carbonate $\left(\mathrm{CaCO}_{3}\right)$ as the main component and are good for source of calcium. Following heat treatment, $\mathrm{CaCO}_{3}$ in the shell is converted to calcium oxide $(\mathrm{CaO})$, which is known to have antibacterial activity (Sawai et al., 2001). Oyster shell calcium powder has been used to improve in the shelf life of sev- 
eral foods, including noodles, fried chicken, sardine balls (Suhara, 1995), kimchi (Choi et al., 2006), tofu (Kim et al., 2007), and pork sausage (Lee et al., 2011). As $\mathrm{CaO}$ is classified as acidity regulator in the food additives database (MFDS, 2013), some studies showed that $\mathrm{CaO}$ solution resulted in strong alkaline range of $\mathrm{pH}$ 11.0-12.5 (Sawai et al., 2001; Yeon, 2006). However, the addition of oyster shell calcium powder and its effect on the functional properties of meat products has not yet been fully studied. Therefore, this study was conducted to evaluate the effects of oyster shell calcium powder (OSCP) as a substitute for phosphates in the curing agent on the properties of restructured pork ham added with the low $\mathrm{NaCl}$ and $0.5 \%$ whey protein.

\section{Materials and Methods}

\section{Processing and sampling}

Certified organic grade vacuum-packed, refrigerated lean pork was obtained from Goesan Doorae Food Inc. (Goesan, Korea). Basic formulation (Table 1) for restructured pork ham was as followed: lean pork $(88.3 \%)$, water $(8.8 \%)$, natural antibiotics $(0.01 \%)$, fructo-oligosaccharide $(0.7 \%)$, glutinous rice powder $(1.8 \%)$, and seasoning $(0.3 \%)$. Manufacturing process (Fig. 1) was as following: the mixed blends were placed in a retainer $(18.0 \times 6.0 \times 4.5$ $\mathrm{cm}^{3}$ ), dried for $25 \mathrm{~min}$, cooked at $55^{\circ} \mathrm{C}$ for $13 \mathrm{~min}$ using sawdust, and then cooked to an internal temperature of $72^{\circ} \mathrm{C}$ in a smokehouse (Bastramat 1500 ; Bayha \& Strackbein Gmbh, Germany). The cooked ham was cooled by spraying with water and kept at $4^{\circ} \mathrm{C}$ for $12 \mathrm{~h}$ before packaging under vacuum. The samples were stored at $4^{\circ} \mathrm{C}$, and quality properties were evaluated at the meat science laboratory of Chungbuk National University.

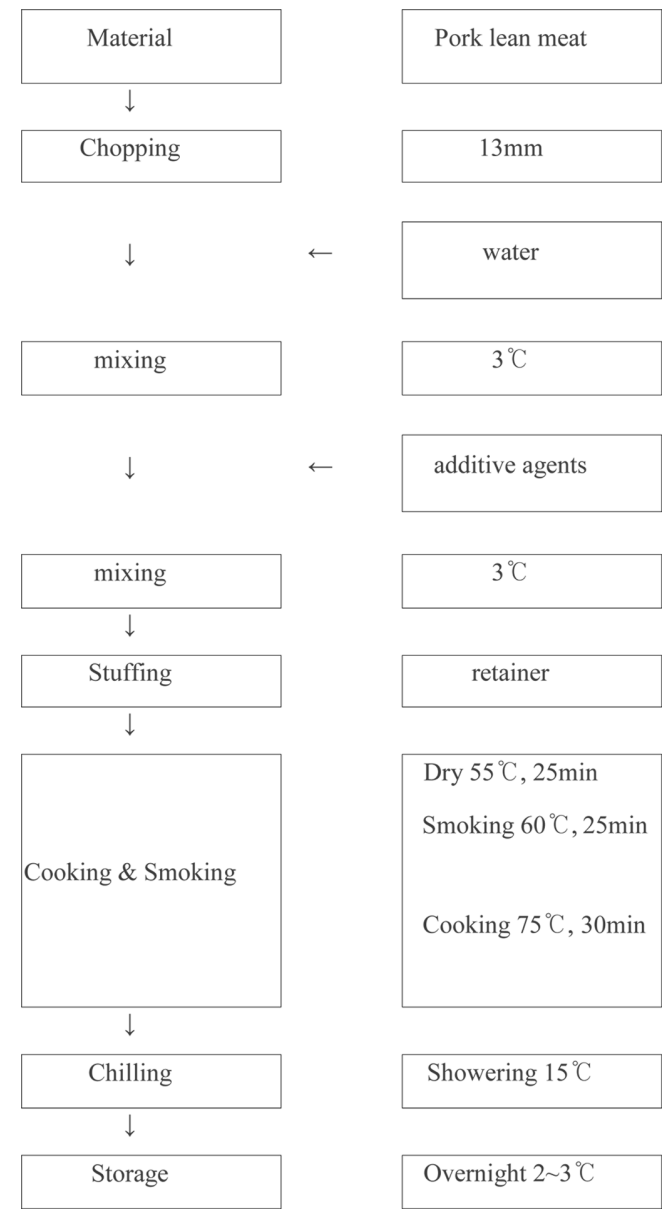

Fig. 1. Manufacturing process of restructured pork ham.

\section{pH}

Using a homogenizer (Nihonseiki, Japan), $10 \mathrm{~g}$ of sample was homogenized in $100 \mathrm{~mL}$ of distilled water for 30 $\mathrm{s}$ at $7000 \mathrm{rpm}$. The $\mathrm{pH}$ levels of the homogenate was determined using a pH meter (Mettler Delta 340; MettlerToledo, Ltd, UK).

Table 1. Experimental design for restructured pork hams (Unit; \%)

\begin{tabular}{ccccccc}
\hline \hline Items* & T1 & T2 & T3 & T4 & T5 & T6 \\
\hline Lean meat & 88.3 & 88.3 & 88.3 & 88.3 & 88.3 & 88.3 \\
Ice & 8.8 & 8.8 & 8.8 & 8.8 & 8.8 & 8.8 \\
Natural antibiotics & 0.01 & 0.01 & 0.01 & 0.01 & 0.01 & 0.01 \\
Fructooligosaccharide & 0.7 & 0.7 & 0.7 & 0.7 & 0.7 & 0.7 \\
Seasoning & 0.3 & 0.3 & 0.3 & 0.3 & 0.3 & 0.3 \\
Glutinous rice powder & 1.8 & 1.8 & 1.8 & 1.8 & - & 1.8 \\
STPP** & - & 0.30 & - & 1.50 & 1.50 & 1.50 \\
Salt & - & - & 1.50 & 0.50 & 0.50 & 0.50 \\
Whey protein & - & - & 0.50 & 0.15 & 0.30 & 0.50 \\
OSCP*** & - & - & - & 102.06 & 102.21 & 102.41 \\
\hline Total & 99.91 & 100.21 & 101.91 & & - \\
\hline
\end{tabular}

*T1 (no additive), T2 $(0.3 \% \mathrm{STPP}), \mathrm{T} 3(1.5 \% \mathrm{NaCl}+0.5 \%$ whey protein), T4 $(1.5 \% \mathrm{NaCl}+0.5 \%$ whey protein $+0.15 \% \mathrm{OSCP}), \mathrm{T} 5(1.5 \%$ $\mathrm{NaCl}+0.5 \%$ whey protein $+0.3 \% \mathrm{OSCP})$, and $\mathrm{T} 6(1.5 \% \mathrm{NaCl}+0.5 \%$ whey protein $+0.5 \% \mathrm{OSCP})$; ${ }^{*}$ Sodium tripolyphosphate; $* * * \mathrm{Oyster}$ shell calcium powder 


\section{Color}

The $L^{*}, a^{*}, b^{*}$ values were determined on the surface of freshly cut of ham by using a Spectro Colormeter (Model JX-777; Color Techno. System Co., Japan) calibrated to the white plate $\left(L^{*}, 89.39 ; a^{*}, 0.13 ; b^{*},-0.51\right) . L^{*}, a^{*}, b^{*}$ values describe the Hunter lab color system ( $\mathrm{L}^{*}=$ lightness, $a^{*}=$ redness, $b^{*}=$ yellowness) by using a white fluorescent light (D65) as light source. Each measurement was performed six times, and mean values were determined to represent the assay result.

\section{Water-holding capacity (WHC)}

The centrifugation method described by (Laakkonen et al., 1970) was used to measure water holding capacity (WHC). Restructured pork ham sample $(0.5 \pm 0.05 \mathrm{~g})$ from each treatment group was placed in a centrifugation tube with filter units, heated for $20 \mathrm{~min}$ at $80^{\circ} \mathrm{C}$, and then cooled for $10 \mathrm{~min}$. Samples were centrifuged at $2000 \mathrm{~g}$ for $10 \mathrm{~min}$ at $4^{\circ} \mathrm{C}$, following which the WHC was calculated as the change in sample weight.

\section{Proximal analysis}

Moisture, protein, lipid, and ash were assayed according to the AOAC methods (1995).

\section{Cooking loss}

A 3-cm-thick slice (weight $100 \pm 5 \mathrm{~g}$ ) cut from restructured pork ham was placed into a polypropylene bag, cooked for $40 \mathrm{~min}$ at $7^{\circ} \mathrm{C}$ in a water-bath, and cooled down to room temperature. Cooking loss was calculated by the weight difference of samples before and after cooking.

\section{Shear force test}

A 3-cm-thick slice (weight $100 \pm 5 \mathrm{~g}$ ) cut from restructured pork ham was placed into a polypropylene bag, cooked for $40 \mathrm{~min}$ at $70^{\circ} \mathrm{C}$ in a water-bath, and then cooled for $30 \mathrm{~min}$. Samples were cut into $1 \times 2 \times 1 \mathrm{~cm}$ (width $\times$ length $\times$ height), pieces and max weight were measured by a Shearing, Cutting Test using a Rheo meter (Model
Compac-100; Sun Scientific Co., Japan) under the following operational conditions: table speed of $110 \mathrm{~mm} / \mathrm{min}$, graph interval of $20 \mathrm{~ms}$, and load cell (max) of $10 \mathrm{~kg}$, compression rate $80 \%$, diameter of load cell $12.73 \mathrm{~mm}$ using the R.D.S (Rheology Data System) version 3.0.

\section{Texture profile analysis (TPA)}

A 3-cm-thick slice (weight $100 \pm 5 \mathrm{~g}$ ) cut from restructured pork ham was placed into a polypropylene bag, cooked for $40 \mathrm{~min}$ at $70^{\circ} \mathrm{C}$ in a water-bath, and then cooled for $30 \mathrm{~min}$. Samples were cut into $1 \times 1 \times 1 \mathrm{~cm}$ (width $\times$ length $\times$ height), A double compression cycle test. Texture Profile Test using a Rheo meter (Model Compac100; Sun Scientific Co., Japan) under the following operational conditions: table speed of $60 \mathrm{~mm} / \mathrm{min}$, and load cell (max) of $4 \mathrm{~kg}$, using the R.D.S (Rheology Data System) version 3.0 .

\section{Statistical analysis}

Statistical analyses were carried out using the GLM (Generalized Linear Model) procedure of the SAS package (Statistical analysis system: The SAS system Release 9.01, 2002). Means were compared using the Duncan's multiple range test at a level of significance of $p<0.05$.

\section{Results and Discussion}

\section{Effect of OSCP addition on proximate analysis of restructured pork ham}

The proximate analysis of the effect of oyster shell calcium powder (OSCP) addition on restructured pork ham is shown in Table 2. Significant differences were observed $(p<0.05)$ in moisture, fat, and protein contents of restructured pork ham among the treatments. Because the moisture content of restructured pork hams can be affected by different concentration of ingredients such as phosphate, OSCP, and whey protein among treatments. And the change of moisture content in ham resulted in the change of fat and protein content ratio in ham. Further-

Table 2. Effect of oyster shell calcium powder addition on proximate analysis of restructured pork hams*

\begin{tabular}{ccccc}
\hline \hline Items & Moisture (\%) & Protein (\%) & Fat (\%) & Ash (\%) \\
\hline T1 & $67.61 \pm 0.60^{\mathrm{d}}$ & $26.86 \pm 0.76^{\mathrm{a}}$ & $4.87 \pm 0.03^{\mathrm{a}}$ & $0.75 \pm 0.16^{\mathrm{c}}$ \\
T2 & $67.85 \pm 0.36^{\mathrm{d}}$ & $26.39 \pm 0.61^{\mathrm{a}}$ & $4.80 \pm 0.26^{\mathrm{a}}$ & $0.94 \pm 0.09^{\mathrm{c}}$ \\
T3 & $70.51 \pm 0.97^{\mathrm{c}}$ & $23.96 \pm 0.29^{\mathrm{b}}$ & $4.48 \pm 0.38^{\mathrm{a}}$ & $1.73 \pm 0.16^{\mathrm{b}}$ \\
T4 & $71.16 \pm 0.36^{\mathrm{cb}}$ & $23.05 \pm 0.37^{\mathrm{bc}}$ & $3.89 \pm 0.10^{\mathrm{b}}$ & $1.91 \pm 0.12^{\mathrm{b}}$ \\
T5 & $71.68 \pm 0.37^{\mathrm{ab}}$ & $22.38 \pm 0.65 \mathrm{~d}^{\mathrm{cd}}$ & $3.65 \pm 0.31^{\mathrm{b}}$ & $2.30 \pm 0.11^{\mathrm{a}}$ \\
T6 & $72.21 \pm 0.37^{\mathrm{a}}$ & $21.57 \pm 0.52^{\mathrm{d}}$ & $3.75 \pm 0.10^{\mathrm{b}}$ & $2.33 \pm 0.15^{\mathrm{a}}$ \\
\hline
\end{tabular}

*Treatments are the same as in Table 1.

${ }^{\mathrm{a}-\mathrm{d}}$ Means $\pm \mathrm{SD}$ with different superscript letters indicate significant differences $(p<0.05)$. 
Table 3. Effect of oyster shell calcium powder addition on quality properties of restructured pork hams*

\begin{tabular}{cccc}
\hline \hline Items & $\mathrm{pH}$ & WHC $(\%)^{* *}$ & Cooking loss $(\%)$ \\
\hline T1 & $6.02 \pm 0.02^{\mathrm{c}}$ & $66.61 \pm 0.54^{\mathrm{b}}$ & $3.77 \pm 0.16^{\mathrm{ab}}$ \\
T2 & $5.90 \pm 0.00^{\mathrm{d}}$ & $74.32 \pm 3.38^{\mathrm{a}}$ & $2.92 \pm 0.07^{\mathrm{c}}$ \\
T3 & $6.06 \pm 0.00^{\mathrm{c}}$ & $71.20 \pm 1.26^{\mathrm{ab}}$ & $3.73 \pm 0.16^{\mathrm{ab}}$ \\
T4 & $6.37 \pm 0.02^{\mathrm{b}}$ & $72.05 \pm 1.47^{\mathrm{ab}}$ & $3.78 \pm 0.23^{\mathrm{a}}$ \\
T5 & $6.54 \pm 0.01^{\mathrm{a}}$ & $72.68 \pm 3.20^{\mathrm{a}}$ & $3.46 \pm 0.01^{\mathrm{b}}$ \\
T6 & $6.59 \pm 0.10^{\mathrm{a}}$ & $71.00 \pm 2.49^{\mathrm{ab}}$ & $3.59 \pm 0.16^{\mathrm{ab}}$ \\
\hline
\end{tabular}

*Treatments are the same as in Table 1; **Water holding capacity.

${ }^{\mathrm{a}-\mathrm{d}}$ Means $\pm \mathrm{SD}$ with different superscript letters indicate significant differences $(p<0.05)$.

Table 4. Effect of oyster shell calcium powder addition on Hunter color of restructured pork hams*

\begin{tabular}{cccc}
\hline \hline \multirow{2}{*}{ Items } & \multicolumn{3}{c}{ Hunter color $^{\mathrm{I}}$} \\
\cline { 2 - 4 } & $\mathrm{L}^{*}$ & $\mathrm{a}^{*}$ & $16.54 \pm 0.47^{\mathrm{a}}$ \\
T1 & $78.17 \pm 3.50^{\mathrm{a}}$ & $4.75 \pm 0.98^{\mathrm{ab}}$ & $16.50 \pm 0.22^{\mathrm{a}}$ \\
T2 & $78.07 \pm 1.80^{\mathrm{a}}$ & $4.94 \pm 0.65^{\mathrm{ab}}$ & $15.68 \pm 0.08^{\mathrm{b}}$ \\
T3 & $73.59 \pm 0.71^{\mathrm{b}}$ & $4.82 \pm 0.12^{\mathrm{ab}}$ & $16.54 \pm 0.18^{\mathrm{a}}$ \\
T4 & $74.46 \pm 1.10^{\mathrm{b}}$ & $5.34 \pm 0.31^{\mathrm{a}}$ & $15.73 \pm 0.08^{\mathrm{b}}$ \\
T5 & $68.88 \pm 0.24^{\mathrm{c}}$ & $4.44 \pm 0.07^{\mathrm{b}}$ & $16.40 \pm 0.09^{\mathrm{a}}$ \\
T6 & $69.88 \pm 0.72^{\mathrm{c}}$ & $5.03 \pm 0.14^{\mathrm{ab}}$ & \\
\hline
\end{tabular}

*Treatments are the same as in Table 1.

${ }^{\mathrm{a}-\mathrm{c}}$ Means $\pm \mathrm{SD}$ with different superscript letters indicate significant differences $(p<0.05)$.

${ }^{1)} L^{*}$, lightness; $a^{*}$, redness; $b^{*}$, yellowness.

more, addition of OSCP significantly increased $(p<0.05)$ ash content of restructured pork hams. In a previous report by Lee et al. (2011), the proximate analysis revealed significant differences $(p<0.05)$ in ash content when OSCP was added to pork sausage.

\section{Effect of OSCP addition on quality of restructured pork ham}

Table 3 shows $\mathrm{pH}, \mathrm{WHC}$ and cooking loss values in restructured pork ham. The addition of OSCP significantly increased $\mathrm{pH}$ of restructured pork ham $(p<0.05)$, but did not affect cooking loss values of restructured pork ham. Furthermore, addition of OSCP to the restructured pork ham showed similar water holding capacity compared to T2 group (added with phosphates) and T3 group (added with salt and whey protein). A previous study showed that addition of phosphates can increase the $\mathrm{pH}$ of ham products and addition of salt can decrease the $\mathrm{pH}$ of ham products. (Puolanne et al., 2001). Another study by Ruusunen et al. (2003) showed that addition of phosphates can increase water holding capacity. However, result of this study did not consensus with that of previous study.

In the meat processing, additives like as salt and phosphates can change the isoelectronic point (IEP) of meat. If $\mathrm{pH}$ of meat rises or falls from the isoelectric point, meat proteins have larger space due to increased repulsion forces. Therefore, more water can be retained (Feiner,
2006). In our study, main material of OSCP is $\mathrm{CaO}$. It is determined that addition of OSCP increased the $\mathrm{pH}$ of meat because calcium oxide changed electronical properties of meat protein.

\section{Effect of OSCP addition on hunter color of restruc- tured pork hams}

Table 4 shows the results of hunter color as addition of OSCP to restructured pork ham. The addition of OSCP to the restructured pork ham was significantly lower lightness value in the $0.3 \%$ and $0.5 \%$ groups than the others $(p<0.05)$. Restructured pork ham added with $0.15 \%$ OSCP tended to show the highest redness value compared to the other groups. Also, T3 (1.5\% salt $+0.5 \%$ whey protein) and T5 ( $1.5 \%$ salt $+0.5 \%$ whey protein $+0.3 \%$ OSCP) were resulted in significantly lower yellowness than the others $(p<0.05)$. High $\mathrm{pH}$ can hold many water between the proteins, and white light reflection is minimized and color absorption is increased. Color of meat is very important factor to the consumer who purchase the meat product in market. Also, color of meat is impacted by myoglobin content and $\mathrm{pH}$ in meat. Nitrite is essential additives in the cured meat color (Bak et al., 2013; Feiner, 2006; Honikel, 2008; Mcclure et al., 2011). In this study, it is determined that there is no huge difference in meat color because nitrite was not used in the production of restructured pork ham. 
Table 5. Effect of oyster shell calcium powder addition on texture profile analysis of restructured pork hams*

\begin{tabular}{cccccc}
\hline \hline Items & Shear Force $(\mathrm{g})$ & Hardness (kg) & Cohesiveness (\%) & Springiness (\%) & Chewiness (kg) \\
\hline T1 & $49.00 \pm 16.97$ & $2.10 \pm 0.42^{\mathrm{ab}}$ & $34.61 \pm 5.85$ & $49.17 \pm 5.61^{\mathrm{bc}}$ & $3.55 \pm 0.84^{\mathrm{ab}}$ \\
T2 & $36.75 \pm 21.28$ & $1.78 \pm 0.34^{\mathrm{b}}$ & $29.03 \pm 4.09$ & $44.28 \pm 6.94^{\mathrm{c}}$ & $2.27 \pm 0.62^{\mathrm{b}}$ \\
T3 & $37.20 \pm 16.93$ & $2.99 \pm 1.25^{\mathrm{a}}$ & $27.14 \pm 4.53$ & $40.66 \pm 6.66^{\mathrm{c}}$ & $3.24 \pm 1.21^{\mathrm{ab}}$ \\
T4 & $49.00 \pm 4.76$ & $2.14 \pm 0.69^{\mathrm{ab}}$ & $27.42 \pm 5.99$ & $48.38 \pm 13.21^{\mathrm{bc}}$ & $2.69 \pm 0.71^{\mathrm{ab}}$ \\
T5 & $43.40 \pm 14.57$ & $2.16 \pm 0.41^{\mathrm{ab}}$ & $25.89 \pm 9.10$ & $65.77 \pm 20.49^{\mathrm{ab}}$ & $3.58 \pm 1.53^{\mathrm{ab}}$ \\
T6 & $37.40 \pm 11.88$ & $1.87 \pm 0.42^{\mathrm{b}}$ & $28.80 \pm 5.74$ & $79.94 \pm 15.34^{\mathrm{a}}$ & $4.15 \pm 0.86^{\mathrm{a}}$ \\
\hline
\end{tabular}

* Treatments are the same as in Table 1.

${ }^{\mathrm{a}-\mathrm{c}}$ Means $\pm \mathrm{SD}$ with different superscript letters indicate significant differences $(p<0.05)$.

\section{Effect of OSCP addition on texture profile analysis of restructured pork ham}

The comparison of texture profile analysis of restructured pork hams is shown in Table 5. No significant differences were observed in shear force and cohesiveness values of restructured pork hams among the treatments. The addition of $0.5 \%$ OSCP showed higher chewiness and springiness values of restructured pork ham compared with addition of phosphates, and the hardness values of T4 (0.15\% OSCP) and T5 (0.3\% OSCP) were similar with that of T3 (1.5\% salt and $0.5 \%$ whey protein). According to Caceres et al. (2006) addition of calcium, a divalent cation, establishes bonds between meat proteins, mainly myosin, and favors the formation of a stronger network leading to a firmer meat. The hardness and chewiness of other proteins such as vegetable proteins and tofu has also been reported to be increased following the addition of OSCP (Kim et al., 2007).

\section{Conclusion}

Commercially available oyster shell calcium powder (OSCP) was used as a substitute for phosphate in the production of restructured pork ham. The ash content of restructured pork ham was higher $(p<0.05)$ in the samples formulated with OSCP than that in the other treatment groups. Moreover, the $\mathrm{pH}$ of restructured pork ham was increased by addition of OSCP, and springiness and chewiness values were higher than those of phosphate. The restructured pork ham treated with OSCP had overall properties similar to restructured pork ham cured with phosphate. Thus, the addition of OSCP combined with the low $\mathrm{NaCl}$ and $0.5 \%$ whey protein can be considered as a viable substitute for phosphate in curing agents while maintaining desirable quality characteristics.

\section{Acknowledgements}

This work was supported by the research grant of Chung- buk National University in 2011. This study was also partially supported by Priority Research Centers Program through the National Research Foundation of Korea (NRF) funded by the Ministry of Education, Science and Technology (2009-0093813).

\section{References}

1. AOAC (1995) Official methods of analysis. 13th ed. Association of Official Analytical Chemists. Washington, D.C.

2. Bak, K. H., Gunilla, L., Anders, H. K., Elsa, L., Pere, G., Jacint, A., and Vibeke, O. (2013) The effect of high pressure and residual oxygen on the color stability of minced cured restructured hamat different levels of drying, $\mathrm{pH}$, and $\mathrm{NaCl}$. Meat Sci. 95, 433-443.

3. Caceres, E., Garcia, M. L., and Selgas, M. D. (2006) Design of a new cooked meat sausage enriched with calcium. Meat Sci. 73, 368-377.

4. Choi, Y. M., Whang, J. H., Kim, J. M., and Suh, H. J. (2006) The effect of oyster shell powder on the extension of the shelf life of Kimchi. Food Contol 17, 695-699.

5. Feiner, G. (2006) Meat products handbook: Practical science and technology. Cambridge; UK: Woodhead Publishing.

6. Honikel, H. O. (2008) The use and control of nitrate and nitrite for processing of meat products. Meat Sci. 78, 68-76.

7. Joseph, G. S. and James, N. B. (2007) Cured meat products without direct addition of nitrite or nitrite: what are the issues? Meat Sci. 77, 136-147.

8. Kim, Y. S., Choi, Y. M., Noh, D. O., Cho, S. Y., and Suh, H. J. (2007) The effect of oyster shell powder on the extension of the shelf life of tofu. Food Chem. 103, 155-160.

9. Laakkonen. E., Wellington, G. H., and Skerbon, J. W. (1970) Low temperature longtime heating of bovine. I. Changes in tenderness, water binding capacity, $\mathrm{pH}$ and amount of watersoluble component. J. Food. Sci. 35, 175-177.

10. Lee, J. J., Park, S. H., Choi, J. S., Kim, J. H., Lee, S. H., Choi, S. H., Choi, Y. I., and Jung, D. S. (2011) Effect of oyster shell powder on quality properties and storage stability of Emulsion-type pork sausages. Korean J. Food Sci. An. 31, 469476.

11. Manzoor, A. S., Sowriappan, J. D. B., and Shabir, A. M. (2014) Plant extrancts as natural antioxidants in meat and meat products. Meat sci. Inpress, Accepted Manuscript, available on- 
line 24 April 2014.

12. Mcclure, B. N., Joseph, G. S., Kim, Yuan, H. K., and Gary, A. S. (2011) The effects of lactate on nitrosylmyoglobin formation from nitrire and metmyoglobin in a cured meat system. Food Chem. 129, 1072-1079.

13. MFDS (Ministry of Food and Drug Safety) (2013) Food additives database.

14. Park, J. I., Seo, T. S., and Jang, A. R. (2012b) Effect of dried yam extrancts on sausage quality during cold storage. Korean J. Food Sci. An. 32, 820-827.

15. Park, J. S., Kim, H. S., and Chin, G. B. (2012a) The antioxidant of Yacon (Polymnia sonchifoliaty) and its application to the pork patties as a natural antioxidant. Korean J. Food Sci. An. 32, 190-197.

16. Park, K. S., Choi, Y. I., Lee, S. H., Kim, C. H., and and Auh, J. H. (2008) Application of functional carbohydrates as a substitute for inorgarnic polyphosphate in pork meat processing. Korean J. Food Sci. Technol. 40, 118-121.

17. Puolanne, E. J., Ruudunen, M. H., and Vainionpaa, J. I. (2001) Combined effects of $\mathrm{NaCl}$ and raw meat $\mathrm{pH}$ on water holding in cooked sausage with and without added phosphate. Meat Sci. 58, 1-7.

18. Ruusunen, M., Vainionpaa, J., Puolanne, Lyly, E. M., Lahteenmaki, L., Niemisto, M., and Ahvenainen, R. (2003) Physical and sensory properties of low-salt phosphate-free frankfurt- ers composed with various ingredients. Meat Sci. 63, 9-16.

19. SAS (2002) The SAS System Release 9.1, SAS Institute Inc., Cary, NC.

20. Sawai, J., Hirokazu, S., and Hiromitsu, K. (2001) Kinetic analysis of the bactericidal action of heated scallop-shell powder. Int. J. Food Microbiol. 71, 211-218.

21. Song, D. J. (1993) Changes in freshness of spent layer meat with additive levels of sodium chloride and phosphates. $J$. Inst. Develop. of Livestock Prod. 20, 9-19.

22. Suhara, H. (1995) Application of antimicrobial calcium agent in food production. Food Indus. 38, 32-44.

23. Tompkin, R. B. (1983) Indirect antimicrobial effects in foods: phosphate. J. Food Safety. 6, 13-27.

24. USDA-FSIS (1982) Meat and poultry products: phosphate and sodium hydroxide. Federal Register 47, 1079.

25. Virpi, E. K., Merja, U. M. K., and Christel J. E. L. (2006) High phosphorus intakes acutely and negatively affect $\mathrm{Ca}$ and bone metabolism in a dose-dependant manner in healthy young females. British J. Nutrition 96, 545-552.

26. Xiong, Y. (2005) Role of myofibrillar proteins in water-binding in brine-enhanced meats. Food Res. Int. 38, 281-287.

27. Yeon, J. H. (2006) Bactericidal effect of calcium oxide $(\mathrm{CaO})$ for the reduction of foodborne pathogens. Chung-ang University master's thesis.

(Received 2014.4.3/Revised 2014.5.10/Accepted 2014.5.10) 